\title{
KONSEP PEMBELAJARAN FIQH DALAM PERSPEKTIF KESEHATAN REPRODUKSI
}

\author{
Sanusi \\ STAIN Kudus, Jawa Tengah, Indonesia \\ sanusipasca@gmail.com
}

\begin{abstract}
Abstrak
Dilatarbelakangi oleh permasalahan pendidikan di Indonesia dewasa ini yang dinilai semakin kompleks, penulis berupaya mengkaji tentang pembelajaran fiqh berdasarkan kesehatan reproduksi. Dalam pelaksaannya kajian ini menggunakan pendekatan kepustakaan dengan metode analisis deskriptif. Pembelajaran Fiqh berdasarkan kesehatan reproduksi adalah konsep pengembangan materi Fiqh yang dihasilkan dengan meninjau kurikulum sebelumnya yang dianggap tidak sadar dengan masalah remaja, khususnya dalam konteks kesehatan reproduksi. Permasalahan remaja seringkali berakar dari kurangnya informasi dan pemahaman serta kesadaran akan pentingnya menjaga kesehatan reproduksi. Di sisi lain, remaja sendiri mengalami perubahan fisik yang cepat. Harus ada keyakinan bersama bahwa membangun generasi penerus yang berkualitas perlu dimulai sejak anak, bahkan sejak dalam kandungan. Konsep pembelajaran fiqh berbasis kesehatan reproduksi merupakan sebuah tawaran pengembangan materi mata pelajaran fiqh madrasah aliyah terkait dengan tema-tema tertentu yang berhubungan dengan kesehatan reproduksi, seperti materi, zina, iddah dan lainnya.
\end{abstract}

Kata kunci: Konsep Pembelajaran, Fiqh, Kesehatan Reproduksi 


\begin{abstract}
LEARNING CONCEPTS OF FIQH IN REPRODUCTIVE HEALTH PERSPECTIVE. Effected by the problem of education in Indonesia which is rated increasingly complex, the author seeks to investigate about Figh learning based on reproductive health. In the implementation, this study uses library research by applying descriptive analysis method. Learning Figh based on reproductive health is the concept of the development of material generated by reviewing the Figh of curriculum previously which was deemed not aware with the problems of youth, particularly in the context of reproductive health. Teenage problems often stem from a lack of information and understanding and awareness of the importance of maintaining the reproductive health. On the other hand, teens themselves are experiencing rapid physical changes. Therefore, should be a shared belief that building the qualified next generation need to be started since the child, even in the womb. The concept of learning fiqh based on reproductive health is an offer of material development subjects of figh in Islamic Senior High School (madrasah aliyah) related to specific themes related to reproductive health, such as the material of zina, iddah and so on.
\end{abstract}

Keywords: learning concept, Fiqh, reproductive health

\title{
A. Pendahuluan
}

Permasalahan pendidikan di Indonesia dewasa ini dinilai semakin kompleks. Hal ini ditunjukkan oleh kenyataan yang semakin memperihatinkan diberbagai dimensi, baik dimensi internal maupun dimensi eksternal. Dimensi-dimensi eksternal pendidikan meliputi dimensi sosial, politik, ekonomi, dan budaya.

Arus globalisasi menjadi titik penting untuk menjadi sorotan, karena ia merupakan trend abad ke-21 yang sangat kuat pengaruhnya terhadap berbagai sektor kehidupan, termasuk pada sektor pendidikan. Di era globalisasi, kehidupan dan peradaban manusia mengalami banyak perubahan, baik karena pengaruh teknologi yang semakin canggih maupun pengaruh sosial, dan budaya yang mengglobal. Maka dalam merespon fenomena itu, manusia berpacu mengembangkan pendidikan baik di bidang ilmu-ilmu sosial, ilmu alam, ilmu pasti, ilmu terapan serta ilmu-ilmu lainnya. Namun bersamaan dengan itu, ditengah puncak kemajuan ada banyak hal 
yang terabaikan yang menghantarkan pada sejumlah krisis dalam kehidupan berbangsa dan bernegara. Salah satunya yang menjadi sorotan penting adalah menyangkut merosotnya moral bangsa khususnya dikalangan pelajar dan remaja. Krisis moralitas yang terusmenerus menggerus bangsa ini pada gilirannya, peranan dan fungsi serta efektivitas pendidikan agama sebagai pemberi nilai spiritual terhadap kehidupan keberagamaan masyarakat dipertanyakan.

Beberapa di antara contoh dari kasus moralitas yang melanda bangsa ini, sebagai fakta empiris terkait meningkatnya angka perilaku penyimpangan di kalangan remaja atau pelajar sebagaimana yang sering muat pada beberapa pemberitaan di media massa yang cukup mencengangkan terkait pemberitaan mengenai penyimpangan yang dilakukan oleh pasangan muda-mudi yang notabene menyandang status sebagai remaja dan pelajar. Bentuk penyimpangan itu berupa "seks bebas" dan bentuk penyimpangan-penyimpangan lainnya.

Ironisnya, pelaku penyimpangan tersebut bukan hanya dari kalangan Sekolah Menengah Umum (SMU) saja, melainkan pelajar Madrasah Aliyah pun menjadi bagian dari pelaku perilaku penyimpangan tersebut. Hal ini secara spontan menyedot perhatian sekaligus mencoreng dunia pendidikan, khususnya pendidikan yang berlabel agama Islam. Namun konteks perspektif penulis, tidak sepatutnya pelaku perilaku penyimpangan yang dilakukan pelajar sebagai objek kambing hitam yang sepenuhnya dipersalahkan.

Bertolak dari paparan di atas, justru tanpa disadari bahwa pelajar adalah bukan hanya sebagai pelaku yang dipersalahkan tetapi di sisi lain ia juga sebagai bagian dari korban yang masih perlu dibina serta harus diperjuangkan atas terpenuhinya mendapatkan hakhak untuk memperoleh informasi dan mendapatkan pemahaman atas dampak panjang dari tindakan penyimpangan tersebut. Tidak menutup kemungkinan perilaku penyimpangan tersebut adalah sebagai sebab dari terputusnya informasi, dalam arti lain, institusi pendidikan kurang mengakomodir segala kebutuhan informasi. Hal ini dapat kita lihat dari sajian-sajian dalam buku materi mata pelajaran agama Islam yang cenderung teoritis tetapi miskin nilai.

Berangkat dari pemaparan di atas, penulis tertarik untuk melakukan pengkajian dan penelusuran terkait materi pelajaran fiqh 
di Madrasah Aliyah secara lebih mendalam. Pertanyaannya, sejauh mana peran dan eksistensi materi mata pelajaran Fiqh yang diajarkan di madrasah sebagai respon atas problem yang tidaak pernah terurai dan terselesaaikan? Dalam hal ini, menurut penulis penting untuk dikaji kembali sebagai langkah preventif agar perilaku menyimpang di kalangan remaja dan pelajar dapat diminimalisir mungkin khususnya di institusi pendidikan berlabel agama Islam.

\section{B. Pembahasan}

\section{Karakteristik Pembelajaran Fiqh Madrasah Aliyah}

\section{a. Pengertian}

Sebelum mengkaji lebih jauh mengenai pembelajaran Fiqh secara utuh, perlu penulis paparkan terlebih dahulu dari beberapa istilah di atas. Definisi Pembelajaran sebagaimana disebutkan dalam UU No. 20 Tahun 2003 tentang Sisdiknas Pasal 1 Ayat 20 adalah proses interaksi peserta didik dengan pendidik dan sumber belajar pada suatu lingkungan belajar. Berdasarkan pengertian di atas terdapat beberapa unsur utama dalam proses pembelajaran yaitu peserta didik, pendidik dan sumber media belajar. Di mana di dalamnya terjadi proses hubungan timbal balik yang saling mempengaruhi antara peserta didik dan pendidik. Konsep pembelajaran juga pada dasarnya merupakan konversi dari istilah proses belajar mengajar yang selama ini digunakan. Sebagaimana yang dikemukakan Sapardi Djoko Damono, menurutnya, Pada prinsipya antara istilah pembelajaran dan proses belajar mengajar mempunyai makna yang sama yang menunjukkan sebuah proses timbal balik antara siswa dan guru. Namun belakangan ini istilah mengajar sudah tidak popular lagi dalam dunia pendidikan di Indonesia. Yang kini lebih popular dan biasa diucapkan adalah istilah "pembelajaran" sejalan dengan semangat perubahan yang terjadi (Damono, 2007: 16).

Pengertian di atas tampaknya sedikit berbeda dengan apa yang dikemukakan Oemar Hamalik, menurutnya, pembelajaran adalah suatu kombinasi tersusun unsur-unsur manusiawi material, fasilitas, perlengkapan dan prosedur yang saling mempengaruhi dalam mencapai tujuan pembelajaran. Manusia yang terlibat dalam sistem pembelajaran terdiri dari anak didik, guru dan tenaga lainnya. 
Material meliputi buku-buku, film, audio, dan lain-lain. Fasilitas dan perlengkapan terdiri dari ruang kelas, perlengkapan audio visual, dan juga komputer. Sedangkan prosedur meliputi jadwal, metode penyampaian, belajar, dan lain-lain. Unsur-unsur tersebut saling berhubungan (interaksi) antara satu unsur dengan unsur yang lain (Hamalik, 1995: 57).

Berdasarkan penjelasan dari beberapa istilah di atas dapat disimpulkan bahwa pembelajaran merupakan proses timbal balik antara siswa dan guru atau pun antara siswa dengan siswa yang didalamnya terdapat unsur-unsur material dan prosedur yang saling mempengaruhi dalam mencapai tujuan pembelajaran.

Sedangkan Pengertian fiqh secara umum yaitu sebagai suatu pengetahuan hukum Islam yang dirumuskan para ahli hukm Islam (mujtahid) melalui proses penalaran terhadap ayat-ayat al-Qur'an dan teks hadits yang berhubungan dengan perbuatan manusia yang berakal dan dewasa (Muhammad, dkk., 2010: 13). Dalam konteks pembahasan fiqh di sini, fiqh yang dimaksud penulis adalah salah satu dari mata pelajaran Pendidikan Agama Islam (PAI) yang berhubungan dengan hukum, aturan-aturan dan tata cara ibadah kepada Allah Swt. yang diajarkan di Madrasah Aliyah. Dalam hal ini, Fiqh juga merupakan salah satu bagian mata pelajaran Pendidikan Agama Islam yang diarahkan untuk menyiapkan peserta didik untuk mengenal, memahami, menghayati dan mengamalkan hukum Islam yang kemudian menjadi dasar pandangan hidupnya (way of life) melalui kegiatan bimbingan, pengajaran, latihan penggunaan, pengamalan dan pembiasaan.

Dari beberapa pandangan di atas dapat penulis simpulkan mengenai pembelajaran Fiqh Madrasah Aliyah, yaitu proses belajar mengajar yang dilakukan secara sadar, terarah dan terencana yang di dalamnya terdapat pembahasan mengenai hukum-hukum Islam dan aturan-aturan serta tata cara ibadah kepada Allah Swt.

Selain dari pada itu juga, Mata pelajaran Fiqh di Madrasah Aliyah merupakan salah satu mata pelajaran Pendidikan Agama Islam (PAI) yang merupakan peningkatan dari Fiqh yang telah dipelajari oleh peserta didik di Madrasah Tsanawiyah/SMP. Upaya peningkatan tersebut dilakukan dengan cara mempelajari, 
memperdalam serta memperkaya kajian Fiqh baik yang menyangkut aspek ibadah maupun muamalah, yang dilandasi oleh prinsip-prinsip dan kaidah-kaidah Usul Fiqh serta menggali tujuan dan hikmahnya, sebagai persiapan untuk melanjutkan ke pendidikan yang lebih tinggi dan untuk hidup bermasyarakat. Secara substansial, mata pelajaran Fiqh memiliki kontribusi dalam memberikan motivasi kepada peserta didik untuk mempraktikkan dan menerapkan hukum Islam dalam kehidupan sehari-hari sebagai perwujudan keserasian, keselarasan, dan keseimbangan hubungan manusia dengan Allah SWT, dengan diri manusia itu sendiri, sesama manusia, makhluk lainnya ataupun lingkungannya (Lampiran Peraturan Menteri Agama Republik Indonesia).

\section{b. Tujuan dan Fungsi Pembelajaran Fiqh di Madrasah Aliyah}

Tujuan merupakan komponen yang sangat penting dalam sistem pembelajaran. Tujuan pembelajaran juga merupakan target yang hendak dicapai dari rangkaian proses. Di dalam tujuan ini memungkinkan pada suatu bentuk proses capaian untuk menentukan "mau dibawa ke mana siswa, dan apa yang harus dimiliki oleh siswa setelah proses belajar mengajar", hal ini tergantung pada tujuan yang ingin dicapai. Ada pun tujuan pembelajaran Fiqh di Madrasah Aliyah sebagaimana yang tercantum dalam Lampiran 3C Bab VIII Peraturan Menteri Agama Republik Indonesia Nomor 2 Tahun 2008, adalah bertujuan untuk membekali peserta didik agar dapat:

1. Mengetahui dan memahami prinsip-prinsip, kaidah-kaidah dan tata cara pelaksanaan hukum Islam baik yang menyangkut aspek ibadah maupun muamalah untuk dijadikan pedoman hidup dalam kehidupan pribadi dan sosial.

2. Melaksanakan dan mengamalkan ketentuan hukum Islam dengan benar dan baik, sebagai perwujudan dari ketaatan dalam menjalankan ajaran agama Islam baik dalam hubungan manusia dengan Allah SWT, dengan diri manusia itu sendiri, sesama manusia, dan makhluk lainnya maupun hubungan dengan lingkungannya.

Sedangkan fungsi Mata pelajaran Fiqh di Madarasah Aliyah adalah sebagai berikut:

1. Penanaman nilai-nilai dan kesadaran beribadah peserta didik 
kepada Allah Swt. sebagai pedoman mencapai kebahagiaan hidup di dunia dan akhirat.

2. Penanaman kebiasaan melaksanakan hukum Islam di kalangan peserta didik dengan ikhlas dan perilaku yang sesuai dengan peraturan yang berlaku di Madrasah dan masyarakat.

3. Pembentukan kedisiplinan dan rasa tanggung jawab sosial di Madrasah dan masyarakat.

4. Pengembangan keimanan dan ketakwaan kepada Allah Swt. serta akhlak mulia peserta didik seoptimal mungkin, yang telah ditanamkan lebih dahulu dalam lingkungan keluarga.

5. Pembangunan mental peserta didik terhadap lingkungan fisik dan sosial melalui Fiqh Islam.

6. Perbaikan kesalahan-kesalahan, kelemahan-kelemahan peserta didik dalam keyakinan dan pelaksanaan ibadah dalam kehidupan sehari-hari.

7. Pembekalan bagi peserta didik untuk mendalami Fiqh/ hukum Islam pada jenjang pendidikan yang lebih tinggi.

Pembelajaran Fiqh diberikan dengan visi untuk mewujudkan manusia yang bertakwa kepada Allah SWT dan berakhlak mulia, serta bertujuan untuk menghasilkan manusia yang jujur, adil, berbudi pekerti, etis, saling menghargai, disiplin, harmonis dan produktif, baik personal maupun sosial. Pembelajaran Fiqh juga diharapkan dapat menghasilkan manusia yang selalu berupaya menyempurnakan iman, taqwa, dan akhlak, serta aktif membangun peradaban dan keharmonisan kehidupan, khususnya dalam memajukan peradaban bangsa yang bermartabat.

\section{c. Ruang Lingkup Materi Fiqh Madrasah Aliyah}

Secara umum ruang lingkup mata pelajaran Fiqh di Madrasah Aliyah ini meliputi: Fiqh Ibadah, Fiqh Muamalah, Fiqh Munakahat, Fiqh Jinayah, Fiqh Siyasah, dan Ushul Fiqh. Hal ini menggambarkan bahwa ruang lingkup mata pelajaran Fiqh mencakup perwujudan keserasian, keselarasan, dan keseimbangan hubungan manusia dengan Allah Swt., dengan diri sendiri, sesama manusia, makhluk lainnya, maupun lingkungannya.

Ada pun cakupannya secara rinci sebagaimana yang dirumuskan dalam Standar Kompetensi (SK) meliputi: kajian 
tentang prinsip-prinsip ibadah dan syariat dalam Islam; hukum Islam dan perundang-undangan tentang zakat dan haji, hikmah dan cara pengelolaannya; hikmah kurban dan akikah; ketentuan hukum Islam tentang pengurusan jenazah; hukum Islam tentang kepemilikan; konsep perekonomian dalam Islam dan hikmahnya; hukum Islam tentang pelepasan dan perubahan harta beserta hikmahnya; hukum Islam tentang wakaalah dan sulhu beserta hikmahnya; hukum Islam tentang daman dan kafaalah beserta hikmahnya; riba, bank dan asuransi; ketentuan Islam tentang jinaayah, Huduud dan hikmahnya; ketentuan Islam tentang peradilan dan hikmahnya; hukum Islam tentang keluarga, waris; ketentuan Islam tentang Siyaasah Syar'iyah; sumber hukum Islam dan hukum Taklifi; dasar-dasar Istinbaath dalam Fiqh Islam; kaidah-kaidah Ushul fiqh dan penerapannya.

\section{d. Standar Kompetensi Kelulusan Materi Fiqh di Madrasah Aliyah}

Tahapan dalam proses penyusunan kurikulum, terlebih dahulu dilakukan analisis kompetensi yang dibutuhkan untuk bisa melaksanakan tugas-tugas tertentu. Hasil analisis tersebut pada gilirannya menghasilkan Standar Kompetensi Lulusan (SKL). Kompetensi adalah kemampuan berfikir, bersikap dan bertindak secara konsisten sebagai perwujudan dari pengetahuan, sikap dan keterampilan yang dimiliki peserta didik. Sedangkan Standar Kompetensi adalah ukuran kompetensi minimal yang harus dicapai peserta didik setelah mengikuti suatu proses pembelajaran pada satuan pendidikan tertentu (Muhaimin, dkk., 2008: 49)

Standar Kompetensi Lulusan adalah seperangkat kompetensi lulusan yang dibakukan dan diwujudkan dengan hasil belajar peserta didik. Standar ini harus dapat diukur dan diamati untuk memudahkan pengambilan keputusan bagi guru, dosen, tenaga kependidikan lain, peserta didik, orang tua dan penentu kebijaksanaan. Standar bermanfaat sebagai dasar penilaian dan pemantauan proses kemajuan dan hasil belajar peserta didik. (Muhaimin, 2005: 230).

Sedangkan dalam peraturan pemerintah RI No.19 tahun 2005 tentang Standar Nasional Pendidikan (SNP) dikemukakan bahwa, Standar Kompetensi Lulusan adalah kualifikasi kemampuan lulusan yang mencakup pengetahuan, sikap dan keterampilan yang 
digunakan sebagai pedoman penilaian dalam penentuan kelulusan peserta didik dari satuan pendidikan.

Standar Kompetensi Lulusan (SKL) merupakan kriteria dalam menentukan kelulusan peserta didik pada setiap satuan pendidikan, rujukan untuk penyusunan standar-standar pendidikan lain dan merupakan arah peningkatan kualitas pendidikan secara mendasar pada jenjang pendidikan dasar dan menengah, serta merupakan pedoman penilaian dalam penentuan kelulusan peserta didik yang meliputi kompetensi untuk seluruh mata pelajaran, serta mencakup aspek pengetahuan dan sikap.

Sedangkan tujuan dari Standar Kompetensi Lulusan (SKL) adalah sebagai berikut:

1. Mewujudkan standar nasional dan standar institusional kompetensi lulusan.

2. Memberikan acuan dalam merumuskan kriteria, kerangka dasar pengendalian dan quality assurance (jaminan mutu) lulusan.

3. Memperkuat profesionalisme lulusan melalui standarisasi lulusan secara nasional dengan tetap memperhatikan tuntutan institusional, yaitu visi, misi suatu madrasah/sekolah. (Muhaimin, 2005: 230)

Dari penjelaan tujuan Standar Kompetensi Lulusan (SKL) sebagaimana diungkapkan oleh Muhaimin di atas tampaknya berbeda dengan pandangan Mulyasa, menurutnya bahwa Standar Kompetensi Lulusan (SKL) pada jenjang pendidikan dasar bertujuan untuk meletakkan dasar kecerdasan, pengetahuan, kepribadian, akhlak mulia serta keterampilan untuk hidup mandiri dan pendidikan lebih lanjut. Pada satuan pendidikan menengah umum bertujuan untuk meningkatkan keceradasan, pengetahuan, kepribadian, akhlak mulia serta keterampilan untuk hidup mandiri dan pendidikan lebih lanjut. Dan pada satuan pendidikan menengah kejuruan, standar kompetensi lulusan bertujuan untuk hidup mandiri dan mengikuti pendidikan lebih lanjut sesuai dangan kejuruannya. (Mulyasa, 2006: 92).

Standar Kompetensi Lulusan (SKL) Madrasah Aliyah diadopsi dari Peraturan Menteri Pendidikan Nasional (Permen Diknas) Nomor 23 tahun 2006 tentang Kompetensi Lulusan. 
sehingga masing-masing Madrasah Aliyah cukup mengacu pada Permendiknas tersebut. Demikian pula Standar Kompetensi Lulusan Mata Pelajaran (SKKMP) cukup mangacu pada Permendiknas Nomor 23 tahun 2006 tentang Standar Kompetensi Lulusan. Atas dasar itulah Madrasah Aliyah dapat mengembangkan Standar Kompetensi Lulusan sebagaimana tertuang dalam Permendiknas Nomor 23 Tahun 2006 tersebut.

Adapun Standar Kompetensi Lulusan mata pelajaran Fiqh pada Madrasah Aliyah sebagaimana dalam Peraturan Menteri Agama RI No.2 Tahun 2008 adalah siswa dapat Memahami dan menerapkan sumber hukum Islam dan hukum taklifi, prinsip-prinsip ibadah dan syariat dalam Islam, fiqh ibadah, mu'amalah, munakahat, mawaris, jinayah, siyasah, serta dasar-dasar istinbath dan kaidah ushul fiqh. (Lampiran I C-1 Bab III Peraturan Menteri Agama Republik Indonesia nomor 2 tahun 2008 tentangStandar Kompetensi Kelulusan PAI dan Bahasa Arab di Madrasah Aliyah).

e. Pemetaan Fiqh Madrasah Aliyah Berdasarkan Permenag RI No. 2 Tahun 2008.

Berdasarkan Standar Kompetensi (SK) dan Kompetensi Dasar (KD) yang tercantum dalam Permenag RI di atas dapat disimpulkan bahwa materi Fiqh Madrasah Aliyah meliputi Fiqh Ibadah, Fiqh Muamalah, Fiqh Munakahat, Fiqh Jinayah, Fiqh Siyasah, dan Ushul Fiqh. Berikut pemetaan materi Fiqh Madrasah Aliyah berdasarkan Permenag RI di atas:

1. Fiqh Ibadah, meliputi pembahasan mengenai:

a. prinsip-prinsip ibadah dan syariat dalam Islam

b. hukum Islam tentang zakat dan hikmahnya

c. hukum Islam tentang haji dan hikmahnya

d. hikmah kurban dan akikah

e. ketentuan hukum Islam tentang pengurusan jenazah

2. Fiqh Muamalah, meliputi pembahasan mengenai:

a. hukum Islam tentang kepemilikan

b. konsep perekonomian dalam Islam dan hikmahnya

c. hukum Islam tentang pelepasan dan perubahan harta beserta hikmahnya

d. hukum Islam tentang wakalah dan sulhu beserta hikmahnya 
e. hukum Islam tentang daman dan kafalah beserta hikmahnya

f. memahami riba, bank, dan asuransi

3. Fiqh Munakahat, meliputi pembahasan mengenai:

a. memahami hukum Islam tentang hukum keluarga

b. memahami hukum Islam tentang waris

4. Fiqh Jinayat, meliputi pembahasan mengenai:

a. memahami ketentuan Islam tentang jinayat dan hikmahnya

b. memahami ketentuan Islam tentang Huudud dan hikmahnya

c. memahami ketentuan Islam tentang peradilan dan hikmahnya

5. Fiqh Siyasah, meliputi pembahasan mengenai:

a. memahami ketentuan Islam tentang Siyasah Syar'iyah

b. memahami sumber hukum Islam

6. Ushul Fiqh, meliputi pembahasan mengenai:

a. memahami hukum- hukum Syar'i

b. memahami kaidah- kaidah Ushul fiqh

\section{f. Pendekatan Pembelajaran dan Penilaian Fiqh}

1) Pendekatan dalam Pembelajaran Fiqh

Mengacu kepada pemetaan materi Fiqh, berdasarkan Permenag RI Nomor 2 Tahun 2008 di atas, maka materi Fiqh perlu dikembangkan dalam suasana pembelajaran yang terpadu, meliputi:

1. Keimanan, yang mendorong siswa untuk mengembangkan pemahaman dan keyakinan tentang adanya Allah SWT. sebagai sumber kehidupan.

2. Pengamalan, mengkondisikan siswa untuk mempraktekkan dan merasakan hasil-hasil pengamalan isi mata pelajaran Fiqh dalam kehidupan seharihari.

3. Pembiasaan, melaksanakan pembelajaran dengan membiasakan melakukan tata cara ibadah, bermasyarakat dan bernegara yang sesuai dengan materi pelajaran Fiqh.

4. Rasional, usaha meningkatkan kualitas proses dan hasil pembelajaran Fiqh dengan pendekatan yang memfungsikan rasio siswa, sehingga isi dan nilai-nilai yang ditanamkan mudah dipahami dengan penalaran. 
5. Emosional, upaya menggugah perasaan (emosi) siswa dalam menghayati pelaksanaan ibadah sehingga lebih terkesan dalam jiwanya.

6. Fungsional, menyajikan materi Fiqh yang memberikan manfaat nyata bagi siswa dalam kehidupan sehari-hari.

7. Keteladanan, yaitu pendidikan yang menempatkan dan memerankan guru serta komponen Madrasah lainnya sebagai teladan; sebagai cerminan dari individu yang mengamalkan materi pembelajaran Fiqh.

2) Penilaian Hasil Pembelajaran Fiqh

Penilaian merupakan proses yang dilakukan terus menerus sejak perencanaan, pelaksanaan, dan setelah pelaksanaan pembelajaran setiap pertemuan, satuan bahan ajar, maupun satuan waktu. (Sumantoro, dkk: 2007). Penilaian dilakukan terhadap proses dan hasil belajar siswa berupa kompetensi yang mencakup pengetahuan, sikap dan keterampilan serta pengamalan. Penilaian berbasis kelas terhadap ranah kognitif, afektif dan psikomotorik dilakukan secara proporsional sesuai dengan karakteristik materi pembelajaran dengan mempertimbangkan tingkat perkembangan siswa serta bobot setiap aspek dari setiap materi.

a) Pengembangan Penilaian Kognitif

Penilaian aspek kognitif dimaksudkan untuk mengukur pencapain indikator hasil belajar dari segi intelektualitas, yaitu kemampuan menggali, mengolah informasi atau peengetahuan. Proses ini membuat kompetensi anak didik secara kognitif, yaitu kemampuan memberikan pendapat atau tanggapan dan mendeskripsikannya. (Warwanto, dkk., 2009: 67).

b) Pengembangan Penilain Afektif

Penilaian aspek afektif dimaksudkan mengevaluasi anak dari segi afeksi dalam proses pembelajaran. Penilain ini merupakan teknik non tes, yaitu pengukuran yang dilakukan anak didik secara konkret, dari segi penerimaan, partiisipasi dan penentuan sikap (Warwanto, dkk., 2009: 74).

c) Pengembangan Penilaian Psikomotorik

Penilaian aspek psikomotorik dimaksudkan untuk mengeval- 
uasi anak didik dari segi aktivitas yang dilakukan dalam pembelajaran, baik berupa pra-aksi mau pun aksi (Warwanto, dkk., 2009: 79).

Penilaian Fiqh juga perlu diperhatikan adalah prinsip kontinuitas, yaitu guru secara terus menerus mengikuti pertumbuhan, perkembangan, dan perubahan siswa. Penilaiannya tidak saja merupakan kegiatan tes formal, melainkan juga meliputi perhatian terhadap siswa ketika duduk, berbicara, dan bersikap serta pengamatan ketika siswa berada di ruang kelas, di tempat ibadah, dan ketika mereka bermain. Dari berbagai pengamatan itu ada yang perlu dicatat secara tertulis terutama tentang perilaku yang menonjol atau kelainan pertumbuhan yang kemudian harus diikuti dengan langkah bimbingan.

\section{Kesehatan Reproduksi Dalam Pandangan Islam}

Pandangan Islam tentang kesehatan reproduksi tercermin pada ajarannya tentang manusia yang dijadikannya sebagai makhluk Allah yang diciptakan dalam bentuk yang sebaik-baiknya (Q.S. AtTin ayat: 4). Dalam hal ini manusia dibekali keutamaan dibanding makhluk lain. Keutamaan tersebut adalah akal, nafsu dan agama. Akal membedakan manusia dari binatang, nafsu membedakan manusia dengan benda dan agama membedakan manusia sebagai insan mulia. Apresiasi Islam pada seks salah satunya terdapat pada Q.S. Ar-Rum: 21, yang artinya:

"Dan di antara tanda-tanda kekuasaan-Nya ialah Dia menciptakan untukmu istri-istri dari jenismu sendiri, supaya kamu cenderung dan merasa tenteram kepadanya, dan dijadikan-Nya di antaramu rasa kasih dan sayang. Sesungguhnya pada yang demikian itu benar-benar terdapat tanda-tanda bagi kaum yang berpikir".

Ayat di atas menjelaskan bahwa manusia diciptakan berpasangpasangan untuk kemudian terjalin dalam ikatan pernikahan. Pernikahan mempunyai tujuan sebagai proses kelangsungan generasi umat manusia di dunia.

Allah SWT menciptakan hasrat seksual (syahwat) pada manusia. Hasrat seksual adalah fitrah manusia. Namun dalam Islam hubungan seks bukan sekedar sarana untuk melampiaskan hawa nafsu. Salah satu tujuan pernikahan itu sendiri adalah untuk melestarikan keturunan. Dan jima' (hubungan seks) merupakan 
bentuk usaha untuk mewujudkan tujuan memperoleh anak tersebut. (Hawa, 2007: 105)

Di samping Islam mengharamkan untuk memuaskan hasrat seksual di luar ikatan perkawinan, Islam juga melarang keras hubungan sesama jenis, sebagaimana diriwayatakan oleh Ibnu Abbas (Syekh Ali al-Birgawi, 2008: 414), bahwa Rasulullah Saw. bersabda, "Apabila kalian menemukan orang yang melakukan tindakan kaum Nabi Luth, usirlah ia dan asingkanlah dari tengah-tengah kalian". (H.R. Al-Tirmidzi).

Berdasarkan penjelasan di atas, Islam memberikan perhatian besar terhadap kelangsungan hidup manusia, yang mengarahkan manusia kepada jalan yang diridloinya, serta menjadikannya manusia sebagai mahluk sempurna yang diberi bekal potensi untuk mengembangkan generasi melalui proses reproduksi.

Pendidikan Islam (khususnya pesantren), telah banyak mengembangkan mengenai ilmu fiqh yang berkaitan dengan konsep pendidikan seks dan reproduksi sebagaimana yang terdapat dalam kitab-kitab fiqh. Ini menunjukkan bahwa secara normatif wacana tentang seks dan reproduksi bukan barang yang baru dan tabu dalam kitab-kitab fiqh. Hal ini terlihat jelas ketika melihat dan mencermati isi kitab-kitab fiqih seperti, Risalah Al-Mahidh (masalah haid), al-Haidh Wa an-Nifas (kitab haid dan nifas). Secara ringkas dapat dikemukakan bahwa kitab-kitab ini membahas tentang haid, Isthihadhah, kehamilan, persalinan, nifas, hal-hal yang diharamkan bagi perempuan haid dan nifas, cara-cara bersuci dan shalat bagi mereka. (Nuruzzaman, 2005: 144).

Selain kitab di atas ada beberapa kitab klasik fiqh keluarga yang diajarkan di pesantren seperti, Qurrotul 'Uyun dan Uqu Dulljain. Kitab ini memang sederhana tetapi ustadzlah yang akan mengupas tuntas serumit apa pun pertanyaan santri seputar seksologi. (Subakti dan Anggarani, 2008: 72).

Menurut Fatima Mernissi, sebagaimana dikutip Syafiq Hasyim, setidaknya ada dua misi tatkala kitab-kitab fiqh pesantren berbicara tentang seks dan reproduksi. Pertama, kitab-kitab fiqh berbicara tentang seks dan reproduksi dengan tujuan mengcounter budaya seks dan reproduksi masa lalu (pra-Islam). Di mana fenomena 
seksualitas dan reproduksi sebelum Islam masih jauh dari nilai-nilai kemanusiaan dan tidak beradab. Misi kedua, adalah membuat aturanaturan dari pola seksualitas dan reproduksi yang tidak selaras dengan syariat Islam menuju pola seksualitas dan reproduksi yang sehat dan beradab (Hasyim, 2002: 205).

Karena itu, pada dasarnya norma-norma seksualitas dan reproduksi dalam kitab-kitab fiqh dimaksudkan untuk mewujudkan tujuan syariat Islam yakni memelihara kehormatan dan harga diri dan memelihara kesucian keturunan dan hak reproduksi. Ini menunjukkan bahwa Islam senantiasa mengutamakan aspek perilaku dan gaya hidup untuk mewujudkan kesehatan reproduksi manusia.

Berdasarkan pemahaman di atas, menunjukkan bahwa pendidikan kesehatan reproduksi mendapat pijakan dari ajaranajaran fiqh yang cukup kukuh (legitimate). Perhatian kitab-kitab fiqh akan aspek kesehatan organ-organ reproduksi tidak lepas dari fungsi fiqh sebagai penjabaran dari al-Qur'an dan al-Hadits demi upaya mewujudkan kemaslahatan manusia. Dalam konteks ini, fiqh kesehatan reproduksi manusia bukan semata-mata proses biologis, lebih dari itu, secara teologis-normatif reproduksi merupakan perbuatan mulia atau ibadah.

Konsep pendidikan fiqh kesehatan alat-alat reproduksi adalah memberikan tekanan pada pentingnya menjaga alat-alat reproduksi dari berbagai macam penyakit - baik penyakit fisik - biologis maupun psikis-mental. Selain itu, fiqh juga memberikan petunjuk, bimbingan, tuntunan, pengetahuan, dan nilai bagaimana seorang muslim harus bersikap dan mengambil keputusan berkaitan dengan kesehatan organ-organ reproduksinya. Tujuan dari pada itu adalaah mampu melakukan proses-proses reproduksi secara sehat dan akan lahir generasi-generasi yang sehat pula.

\section{Mata pelajaran Fiqh dan permasalahannya}

Berikut ini beberapa realita permasalahan yang terjadi, baik secara umum maupun lebih khusus yang terkait dalam implementasi materi Fiqh baik dalam kerangka kurikulum maupun dalam proses pembelajaran di kelas. 


\section{a. Aspek Kurikulum.}

Sistem pendidikan Nasional, dalam kenyataannya telah berkali-kali mengalami perubahan. Perubahan yang paling esensi dalam sistem pendidikan Nasional ini adalah yang menyangkut perubahan kurikulum, tiga kali perubahan yang terakhir yakni, mulai dari kurikulum 1994, kurikulum 2004 yang terkenal dengan Kurikulum Berbasis Kompetensi, dan Kurikulum 2006 (Kurikulum Tingkat Satuan Pendidikan), dan kurikulum 2013 yang masih dalam proses adaptasi.

Upaya perbaikan sistem pendidikan nasional melalui perubahan kurikulum tampaknya bukan sebagai solusi yang tanpa mendatangkan masalah baru lainnya. Pada saat yang bersamaan, perubahan kurikulum membawa implikasi-implikasi yang beragam, baik negatif maupun positif. Pada kenyataannya, implikasi perubahan kurikulum itu membawa sekian banyak problem yang tidak mudah untuk dipecahkan, dan problem-problem ini tidak hanya dialami oleh para penyelenggara pendidikan di tingkat pusat, akan tetapi juga di daerah, khususnya para pendidik di tingkat satuan pendidikan (sekolah) masing-masing. Pada gilirannya masyarakat pun pada umumnya menanggapi dengan nada sinis dan negatif. Sehingga terkesan pendidikan kita adalah pendidikan yang plinplan ketika ada pergantian Menteri (pendidikan) berganti pula kurikulum, kebijakan kurikulum yang dilaksanakan belum tuntas/ maksimal sudah berganti lagi dengan kurikulum yang baru, siswa menjadi "kelinci percobaan", dan seterusnya (Zainuddin, 2008: 215).

Perubahan kebijakan kurikulum di atas, berimbas pada kurikulum/materi Fiqh Madrasah Aliyah yang mau tidak mau juga harus ikut berubah menyesuaikan perubahan kebijakaan yang ada. Beberapa permasalahan implementasi kurikulum/materi Fiqh Madrasah Aliyah di antaranya:

1. Pada pelaksanaan di lapangan (sekolah) banyak dijumpai bahwa materi Fiqh disajikan lebih terfokus pada pengayaan pengetahuan (kognitif) dan minim dalam pembentukan sikap (afektif) serta pembiasaan (psikomotorik). Hal ini tidak sejalan dengan tujuan pembelajaran Fiqh itu sendiri. Yakni disebutkan bahwa pembelajaran Fiqh bermaksud 
untuk membekali siswa tidak saja pada dataran mengetahui dan memahami pokok-pokok hukum Islam (domain kognitif), akan tetapi juga pada dataran melaksanakan dan mengamalkannya dalam kehidupan sehari-hari. Berdasarkan kenyataan di atas. materi mata pelajaran fiqh belum sepenuhnya berorientasi pada upaya penyelesaian masalah, hal ini terlihat dari karena materi mata pelajaran fiqh yang lebih diarahkan kepada kemampuan peserta didik untuk sebatas memahami konten materi pelajaran yang bersifat dogmatis teoritis, tetapi mengabaikan pengembangan materi yang disesuaikan dengan koteks problem keinian. Sebagai contoh misalnya pada materi pelajaran fiqh Madrasah Aliyah terdapat sejumlah pembahasan yang menjelaskan tentang ketentuan hukum Islam mengenai "zina dan iddah", tetapi konten materi tersebut sebatas berbicara mengenai persoalan "dosa" dan "haram". Penulis menlai hal tersebut merupakan sebuah stagnasi kurikulum yang terjebak pada teoretik dogmatik tetapi kering akan nilai dan makna. sebagai sebuah tawaran terkait dengan tema "zina" perlu dikembangkan melalui pengintegrasian dengan materi pelajaran lain seperti biologi yang berbicara mengenai "kesehatan reproduksi".

2. Dalam Standar Kompetensi Kelulusan materi Fiqh Madrasah Aliyah disebutkan bahwa "siswa dapat memahami dan menerapkan sumber hukum Islam dan hukum taklifi, prinsip-prinsip ibadah dan syariat dalam Islam, fiqh ibadah, mu'amalah, munakahat, mawaris, jinayah, siyasah, serta dasardasar istinbath dan kaidah usul fiqh". (Lampiran Peraturan Menteri Agama Republik Indonesia nomor 2 tahun 2008). Menurut pandangan penulis, merujuk standar kelulusan di atas dinilai belum menyentuh sampai pada tuntutan agar siswa dengan penuh kesadaran mampu mengamalkan ibadah mahdlah dan mu'amalah itu dalam kehidupan sehari-hari. Sehingga bila standar kelulusan hanya dapat memahami dan menerapkan, berarti hanya sampai pada kemampuan kognitif dan psikomotorik saja, belum sampai kepada aspek afektifnya atau kesadaran melaksanakan ibadah dan mu'amalah. 


\section{b. Aspek Pembelajaran \\ 1) Guru}

Diakui atau tidak, keberadaan guru akan selalu menjadi salah satu unsur penting yang menentukan berhasil atau tidaknya pendidikan. Dalam kenyataannya guru masih sangat dominan dalam menentukan berhasil atau tidaknya proses pembelajaran. Karena itu, apa pun formulasi para pakar pendidikan mengenai strategi proses pembelajaran, mau tidak mau harus menempatkan guru dalam posisi strategis di dalamnya.

Peran penting guru sebagai salah satu penentu keberhasilan proses pembelajaran tampaknya tidak dibarengi dengan etos kerja guru selaku tenaga profesional dalam bidang pendidikan. Tidak dapat dipungkiri bahwa dalam prakteknya masih banyak guru yang belum mencerminkan sebagai guru yang mumpuni, profesional dan berkualitas. Sehingga banyak permasalahan-permasalahan yang muncul dari guru itu sendiri dalam melaksanakan tugas dan fungsinya.

Beberapa kelemahan atau kesalahan yang sering dilakukan guru:

1. mengambil jalan pintas dalam pembelajaran,

2. teaching oriented,

3. mengabaikan perbedaan dan potensi siswa,

4. kurang keteladanan.

Selain persoalan di atas, persoalan lain yang berkaitan dengan proses implementasinya juga lebih didominasi pencapaian kemampuan kognitif serta Kurang mengakomodasikan kebutuhan afektif dan psikomotorik, di samping itu kendala lain adalah kurangnya keikutsertaan guru mata pelajaran lain dalam memberi motivasi kepada siswa untuk mempraktekkan nilai-nilai Fiqh dalam kehidupan sehari hari.

2) Siswa

Komponen kedua dalam proses pembelajaran adalah siswa, sebagai sasaran pembelajaran guru di kelas. Kualitas guru yang profesional, metode belajar yang tepat akan ikut menentukan dalam menghasilkan out put SDM (siswa) yang berkualitas. Akan tetapi semua itu juga tidak akan terwujud manakala SDM siswa sangat 
"rendah". Beberapa permasalahan yang mempengaruhi ketidakberhasilan proses pembelajaran fiqih dilihat dari sudut pandang siswa adalah:

1. Kurangnya minat siswa pada pelajaran fiqh, hal ini disebabkan misalnya latar belakang keluarga yang kurang agamis, sehingga partisipasi keluarga dalam proses mengenalkan dan melaksanakan ajaran Islam rendah.

2. Siswa bersikap apatis, pasif, kurang motivasi, kurang minat dalam proses belajar, tidak ada semangat untuk menuntut ilmu.

3. Siswa tidak mempunyai sikap kompetisi, kreatifitas, bekerjasama, tolong-menolong, saling menghargai dengan temannya, dan sebagainya.

4. Kecenderungan sebagian besar siswa yang belajar hanya berorientasi kepada pencapaian hasil berupa angka (nilai) yang bagus di raport, tanpa ada dorongan / kesadaran yang tinggi untuk mengamalkan ilmu tersebut dalam kehidupan sehari-hari.

3) Metode Pembelajaran

Keberadaan metode pembelajaran menempati posisi yang sangat penting dalam aktifitas proses pembelajaran. Penggunaan metode belajar yang tepat akan memberikan kemudahan bagi guru dalam menjalan kantugasnya sebagai pendidik dan pengajar. Keberhasilan atau kegagalan guru dalam menjalankan proses belajar mengajar banyak ditentukan oleh kecakapannya dalam memilih dan menggunakan metode mengajar. Seringkali dijumpai seorang guru memiliki pengetahuan luas terhadap materi yang akan diajarkan, namun tidak berhasil dalam mengajar. Salah satu penyebabnya adalah kurangnya penguasaan metode mengajar (Nasih dan Kholidah, 2009: 31).

Menurut Amin Abdullah, pendidikan Agama Islam (termasuk fiqh) terkesan lebih banyak memfokuskan pada isi atau muatan materi yang harus ditransfer kepada orang lain, dan bukannya pada proses dan metodologi bagaimana sesungguhnya pendidikan Agama Islam dilaksanakan dalam situasi dan zaman yang terus berkembang dan berubah, merupakan persoalan penting yang perlu dikaji 
Demikian juga dikatakan oleh Muhaimin, bahwa kelemahan dari pelaksanaan pendidikan Agama Islam lebih banyak bermuara pada aspek metodologi pembelajaran dan orientasinya yang lebih bersifat normatif, teoritis, dan kognitif (Muhaimin, 2007: 26). Bahkan Mastuhu menyatakan bahwa metode pembelajaran yang berlaku saat ini masih bersifat klasik, dalam arti mewariskan sejumlah materi ajaran agama yang diyakini benar untuk disampaikan kepada anak didik tanpa memberikan kesempatan kepada mereka agar menyikapi materi-materi tersebut secara kritis, mengoreksi, mengevaluasi dan mengomentarinya (Mastuhu, 2002: 17).

Beberapa permasalahan yang sering terjadi berkenaan implementasi metode pembelajaran oleh guru fiqih Madrasah Aliyah adalah:

1. Guru lebih sering menggunakan metode konvensional

2. Dalam proses belajar-mengajar guru kurang memperhatikan, dan sedikit memberi ruang kepada siswa dalam proses keterlibatannya secara penuh.

Di samping hal tersebut lemahnya sumber daya guru dalam pengembangan pendekatan dan metode yang lebih variatif, minimnya berbagai sarana pelatihan dan pengembangan serta rendahnya peran serta orang tua siswa (Departemen Agama RI, 2004: 47).

4) Waktu

Berdasarkan pengkajian yang dilakukan penulis, pembelajaran bidang studi Fiqh menghadapi beberapa kendala, antara lain; waktu yang disediakan terbatas, berhadapan dengan muatan materi yang begitu padat dan memang penting, yakni menuntut pemantapan pengetahuan hingga terbentuk watak dan kepribadian yang berbeda jauh dengan tuntutan terhadap mata pelajaran lainnya.

5) Evaluasi Pembelajaran

Evaluasi merupakan salah satu kegiatan utama yang harus dilakukan oleh seorang guru dalam kegiatan pembelajaran. Dengan evaluasi guru akan mengetahui perkembangan hasil belajar, intelegensi, bakat khusus, minat, hubungan sosial, sikap dan kepribadian siswa. Dalam realitas di lapangan masih terdapat beberapa problem yang diketemukan dalam proses evaluasi siswa 
dari guru bidang studi fiqih, diantaranya:

1. Sistem evaluasi, bentuk-bentuk soal ujian fiqh menunjukkan prioritas utama pada kognitif, dan jarang pertanyaan tersebut mempunyai bobot muatan "nilai" dan "makna" spiritual keagamaan yang fungsional dalam kehidupan sehari-hari.

2. Dalam obyek evaluasi, aspek evaluasi selama ini yang dilakukan lebih berkutat pada aspek kemampuan siswa pada dataran kognitif.

\section{Simpulan}

Permasalahan remaja seringkali berakar dari kurangnya informasi dan pemahaman serta kesadaran akan pentingnya menjaga kesehatan reproduksi. Di sisi lain, remaja sendiri mengalami perubahan fisik yang cepat. Harus ada keyakinan bersama bahwa membangun generasi penerus yang berkualitas perlu dimulai sejak anak, bahkan sejak dalam kandungan. Konsep pembelajaran fiqh berbasis kesehatan reproduksi merupakan sebuah tawaran pengembangan materi mata pelajaran fiqh madrasah aliyah terkait dengan tema-tema tertentu yang berhubungan dengan kesehatan reproduksi, seperti materi, zina, iddah dan lainnya. 


\section{DAFTAR PUSTAKA}

Abdul Munir Mulkhan, dk,. 1998. Rekonstruksi Penidikan dan Tradisi Pesantren Religiusitas Iptek. Yogyakarta: Fakultas Tarbiyah IAIN Sunan Kalijaga-Pustaka Pelajar.

Nasih, Ahmad Munjin dan Lilik Nur Kholidah. 2009. Metode dan Teknik Pembelajaran Pendidikan Agama Islam. Bandung: Refika Adimata,.

Departemen Agama RI, Kurikulum 2004. 2004. Standar Kompetensi. Jakarta : Dirjen Bimbaga Islam.

Muhammad, Husein. dkk. 2010. Fiqih HIV \& AIDS: Pedulikah Kita. Cet. 2. Cirebon: Fahmina Istitut.

Joko Warwanto, Heribertus. 2009. dkk. Pendidikan Religiositas: gagasan isi dan pelaksanaannya. Yogyakarta: Kanisius.

Muhaimin,dkk, 2008. Pengembangan Model KTSP Pada Sekolah dan Madrasah, Jakarta: Raja Grafindo Persada.

--------, 2007. Pengembangan Kurikulum Pendidikan Agama Islam di Sekolah, Madrasah dan Perguruan Tinggi. Jakarta: Raja Grafindo Press.

, 2001. Paradigma Pendidikan Islam Upaya Mengefektifkan Pendidikan Agam Islam di Sekolah. Bandung: Remaja Rosdakarya.

Mulyasa, 2006. Kurikulum Tingkat Satuan Pendidikan. Bandung: Remaja Rosdakarya.

M. Zainuddin. 2008. Reformasi Pendidikan: Kritik Kurikulum dan Manajemen Berbasis Sekolah. Yogyakarta: Pustaka Pelajar.

Mastuhu. 2002. Pendidikan Agama Islam di Perguruan Tinggi Umum; Dinamika Pemikiran Islam di Perguruan Tinggi, Wacana tentang Pendidikan Agama Islam. Jakarta: Logos Wacana Ilmu.

M. Nuruzzaman, 2005. Kiai Husein Membela Perempuan, (Yogyakarta: Pustaka Pesantren. 
Konsep Pembelajaran Fiqh dalam Perspektif Kesehatan Reproduksi

Oemar Hamalik, 1995. Kurikulum dan Pembelajaran. Jakarta: Bumi Aksara.

Sumantoro, dkk. 2007. Silabus Sains,P.Sosial,Matematika,B.Indonesia $S D$ 1. Yogyakarta: Kanisius.

Sapardi Djoko Damono. 2007. Sastra di Sekolah dalam Susastra 5 Jurnal Imu Sastra dan Budaya, volume 3 no 5/2007. Jakarta: HISKI.

Lampiran 3c Bab VIII Peraturan Menteri Agama Republik Indonesia nomor 2 tahun 2008 tentang Standar Isi PAI dan Bahasa Arab di Madrasah Aliyah, 272. 
Sanusi

halaman ini bukan sengaja dikosongkan 